\title{
Zihinsel Yetersizliği Olan Öğrencilere Matematiksel Kavram ve Becerilerinin Öğretimine Yönelik Öğretmenlerin Sınıf İçi Uygulamalarının Belirlenmesi
}

\section{Özel Eğitim Bilim Uzmanı Evgin Çay ${ }^{1 *}$ \\ Doç. Dr. Ahmet Yıkmış ${ }^{2}$}

Geliș tarihi: 24.12.2019

Kabul tarihi: 30.01 .2020

\section{Atıf bilgisi:}

IBAD Sosyal Bilimler Dergisi

Sayı: 7 Sayfa: $69-85$

Yıl: 2020 Dönem: Yaz

This article was checked by Turnitin.

Similarity Index $21 \%$

Bu makalede araştırma ve yayın etiğine uyulmuştur.

${ }_{1}^{1}$ MEB, Türkiye, evgincay35@gmail.com ORCID ID 0000-0002-1139-3939

2 Bolu Abant İzzet Baysal Üniversitesi, Türkiye,avikmis@hotmail.com ORCID ID 0000-0002-1143-1207

* Sorumlu yazar

\section{öz}

$\mathrm{Bu}$ araştırmanın amac1; hafif düzey zihinsel yetersizliği olan öğrencilere matematiksel kavram ve becerilerinin öğretimine yönelik öğretmenlerin sınıflarında yaptıkları uygulamaları incelemektir. Araştırmanın örneklem grubunu Sakarya'da özel eğitim okulunda çalışan 10 özel eğitim öğretmeni olușturmaktadır. Verilerin toplanmasında, görüşme türlerinden yarı yapılandırılmış görüşme tekniğinden yararlanılmıştır. Araştırmacılar tarafından hazırlanan yarı yapılandırılmış görüşme soruları kullanılarak veriler toplanmıştır. Verilerin çözümlenmesinde betimsel analiz kullanılmıştır. Araştırmanın sonunda özel eğitim okulunda çalışan öğretmenler, matematiksel kavram ve becerilerin öğretimi sırasında bireyselleştirilmiş eğitim ve öğretim planı yaptıklarını ifade etmişlerdir. Öğretmenler, matematiksel kavram ve becerilerin öğretimi sırasında öğrencilerin dikkatini çekmeye ve sürdürmeye yönelik öğrencinin yakın çevresinden örnekler verdiğini ifade etmişlerdir.

Anahtar Kelimeler: Zihinsel Yetersizlik, Matematik, Kavram, Beceri. 
Determination Made of the Teachers Regarding Teaching Mathematics Concepts and Skills to the Students with Intellectual Disabilities

\author{
Specialist Evgin Çay ${ }^{*}$ \\ Assoc. Prof. Dr. Ahmet Yıkmış²
}

First received: 24.12 .2019

Accepted: 30.01 .2020

\title{
Citation:
}

IBAD Journal of Social Sciences

Issue: $7 \quad$ Pages: 69-85

Year: $2020 \quad$ Session: Summer

This article was checked by Turnitin. Similarity Index $21 \%$

\begin{abstract}
This study aimed to examine the applications of the teachers regarding the teaching to students with mild intellectual disabilities of mathematical concepts and skills in their classes. Sample group of the study was composed of 10 special education teachers employed in special education schools in Sakarya. Semi-structured interview technique was used in data collection. Data were collected using a semistructured interview form prepared by the researchers. Descriptive analysis technique was utilized to analyze data. Data were summarized and interpreted with the help of descriptive analysis technique. As a result of research, teachers working in special education schools stated that they made an individualized education and training plan during the teaching of mathematics concepts and skills. Teachers stated that they gave examples from the close environment of the student in order to attract and maintain the students' attention during the teaching of mathematical concepts and skills.
\end{abstract}

Keywords: Intellectual Disability, Mathematic, Concept, Skill.

\author{
${ }^{1}$ MEB, Turkey, evgincay35@gmail.com \\ ORCID ID 0000-0002-1139-3939 \\ 2 Bolu Abant İzzet Baysal Universitiy, \\ Turkey, avikmis@hotmail.com \\ ORCID ID 0000-0002-1143-1207
}

* Corresponding Author 
Zihinsel Yetersizliği Olan Öğrencilere Matematiksel Kavram ve Becerilerinin Öğretimine Yönelik Öğretmenlerin Sınıf İçi Uygulamalarının Belirlenmesi

\section{GİRIŞ}

Zihinsel yetersizliği olan bireylerin günlük yaşamlarını ve iş yaşamlarını kolaylaştıran kavramlar ve beceriler bulunmaktadır. Bireylerin günlük yaşamlarında kullandıkları bu beceriler işlevsel beceriler olarak adlandırılmaktadır. Zihinsel yetersizliği olan bireylerin bağımsız olarak yaşamalarını kolaylaştıran ve günlük hayatta kullanabilecekleri beceriler; sosyal beceriler, iş ve meslek becerileri, günlük yaşam becerileri, işlevsel akademik becerileri gibi becerileri içermektedir (Karabulut ve Yıkmış, 2010).

Zihinsel yetersizliği olan bireylerin yaşamlarını başkalarının yardımına gereksinim duymadan ya da daha az gereksinim duyarak sürdürebilmeleri, içinde yaşadığı topluma uyum sağlayabilmeleri okullarda aldıkları özel eğitim hizmetlerinin niteliğine bağlı olmaktadır (Akmanoğlu, 2002; Eldeniz Çetin ve Çay, 2016; Yücesoy, 2002). Zihinsel yetersizliği olan bireylerin gerek eğitim sürecinde gerekse günlük yaşamda işine yarayan ve sorumluluklarını kolaylaştıran becerilerden biri de akademik becerilerdir. Öğrencilerin okul ortamında başarılı olabilmeleri, içinde yaşadığı topluma ayak uydurabilmeleri ve bağımsız olarak yaşayabilmeleri için işlevsel akademik becerileri öğrenmeleri gerekmektedir (Erbaş, 2008). Matematiksel kavram ve becerilerinin öğretimi bu işlevsel akademik becerilerinin içerisinde yer alan önemli alanlardan biri olarak görülmektedir.

Matematik; bireylerin topluma uyum sağlamada önemli disiplin alanlarından bir tanesi olmakla beraber (Tufan ve Aykut, 2018) bireylerin bir konu üzerinde eleştirel düşünmesi, akıl yürütmesi ve karşılarına çıkan problemleri çözebilme becerisi kazandırması bakımından önemli görülmektedir. Matematik, gerek normal gelişim gösteren gerekse yetersizliği olan bireylerin günlük yaşamıyla iç içe olmakla beraber bu tür bireylerin yaşamlarını kolaylaştırmaktadır. $\mathrm{Bu}$ nedenle zihinsel yetersizliği olan öğrencilere matematiksel kavram ve becerilerinin öğretilmesi gerekmektedir (Durmuş ve Y1kmış, 2004; Karabulut ve Y1kmış, 2010).

Eğitim öğretim ortamında öğretilen temel matematik becerileri; rakamları tanıma, temel toplama ve çıkarma işlemleri, çarpma, bölme, problem kurma ve çözme, para, zaman birimlerini öğrenmeyi içermektedir (Yıkmış ve Eldeniz Çetin, 2010). Bu tür kavram ve beceriler soyut olmakla birlikte birbirinin ön koşulu olduğu için birini öğrenmede yetersizlik gösteren bir birey bir sonraki kavram ve beceriyi öğrenmede zorluk yaşayacaktır. Dolayısıyla öğretim planı yapılırken birbirinin ön koşulu olma özelliği göz önünde bulundurulmalıdır (Baykul ve Aşkar, 1987; Baykul, 2016; Yıkmış, 2012).

Zihinsel yetersizliği olan bireyler matematik kavram ve becerilerini öğrenmede ve daha sonra bu becerileri genellemede sorun yaşamaktadırlar (Gürsel, 2010; Katlav, 2008). Zihinsel yetersizliği olan her iki öğrenciden biri bu kavram ve becerileri öğrenmede yetersizlik yaşamakla birlikte matematiksel kavram ve becerilerini öğrenmedeki yetersizliğin a) öğrenciden kaynaklanan b) öğretim yönteminden ve c) matematik içeriğinin özelliklerinden kaynaklandığ 1997; Tracy ve Fanelli, 2000). Öğrencinin soyut kavramları algılama ve yorumlamadaki yetersizliği, kendisinde var olan bilişsel yetersizlikleri matematiksel kavram ve becerilerini günlük yaşamda kullanamamalarına neden olan öğrenci kaynaklı sebeplere örnek verilebilir (Calhoon ve Fuchs, 2003; Gürsel, 2010; Krosbergen ve Van-Luit, 2003; Mercer ve Miller, 1992). Hazırlanan eğitim öğretim planlarının öğrenci düzeyinde olmaması (Gürsel, 2010; Şafak, 2007) diğer nedenler arasında sayılabilir. $\mathrm{Bu}$ nedenle zihinsel yetersizliği olan öğrencilere matematiksel kavram ve becerilerinin öğretimi yapılmadan önce öğrenci seviyeleri dikkate alınarak planlama yapılmalı, öğretilecek beceriler küçük adımlarla verilmeli, kalıcı olması için yeterli tekrarlara yer verilmeli ve somuttan soyuta bir yol izlenmelidir (Gürsel, 2010; Şafak, 2007, Tuncer, 1994). Yetersizliği olan bireylerin yaşamını kolaylaştırması ve yaşamlarında kullanılabilir özelliği olması nedeniyle matematik çok önemli bir yere sahiptir (Kot, 2014; Sönmez, 2014; Yıkmış, 2005).

Yetersizliği olan bireylere matematiksel kavram ve becerilerinin öğretimine yönelik araştırmaların yapıldığı görülmektedir. Eliçin, Dağseven Emecen ve Y1kmış (2013), zihin engelli çocuklara doğrudan öğretim yöntemiyle temel toplama işlemlerinin öğretiminde nokta belirleme tekniği kullanılarak yapılan öğretimin etkililiğini incelemişlerdir. Araştırmaya dört, dokuz ve 20 yaşında üç öğrenci katılmıştır. Denekler arası çoklu yoklama modelinin kullanıldığı araştırmada doğrudan öğretim yöntemiyle toplama işlemlerinin öğretiminde nokta belirleme tekniğinin kullanımının etkili olduğu bulunmuştur. Geçal ve 
Zihinsel Yetersizliği Olan Öğrencilere Matematiksel Kavram ve Becerilerinin Öğretimine Yönelik Öğretmenlerin Sınıf İçi Uygulamalarının Belirlenmesi

Eldeniz Çetin (2017), zihinsel yetersizliği olan öğrencilere eldesiz toplama işleminin öğretiminde tablet bilgisayar aracılığı ile sunulan animasyon programının etkililiğini incelemişlerdir. Çalışma, zihinsel yetersizlik tanısı olan bir kız, iki erkek toplam üç öğrenci ile yürütülmüştür. Denekler arası yoklama evreli çoklu yoklama modelinin kullanıldığı araştırmada deneklerin tablet bilgisayar aracılığı ile sunulan animasyon programı ile toplama işlemlerini öğrendikleri tespit edilmiştir. Kot, Sönmez, Yıkmış ve Cora İnce (2016), doğrudan öğretim yöntemiyle sunulan nokta belirleme tekniğinin işitme yetersizliği olan bireylere eldeli toplama işlemi öğretiminde etkili olup olmadığını belirlemişlerdir. Genel eğitim sınıflarında okuyan 7-11 yaş arasında olan üç işitme yetersizliği olan denek araştırmanın katılımcılarını oluşturmaktadır. Denekler arası yoklama evreli çoklu yoklama modelinin kullanıldığı araştırmada eldeli toplama işlemi becerilerinin öğretiminde doğrudan öğretim yaklaşımına dayalı nokta belirleme tekniğine göre sunulan öğretimin etkili olduğu bulunmuştur. Kot, Sönmez ve Yıkmış (2017), zihinsel yetersizliği olan öğrencilere toplama işlemi öğretiminde doğrudan öğretim yöntemiyle sunulan nokta belirleme tekniği ile sayı doğrusu stratejisini karşılaştırmışlardır. Dönüşümlü uygulamalar modelinin kullanıldığı araştırmaya iki denek katılmıştır. Araştırma sonunda zihinsel yetersizliği olan öğrencilere toplama işlemi öğretiminde nokta belirleme tekniğinin sayı doğrusu stratejisine göre daha etkili ve verimli olduğu tespit edilmiştir. Daugherty Grisham-Brown ve Hemmeter (2001), sabit bekleme süreli öğretim günlük yapılan aktivitelerin içine gömülmüş ve farklı düzeylerde gelişimsel yetersizliği olan öğrencilere sayı sayma becerisinin öğretimini yapmışlardır. Davranışlar arası çoklu yoklama modelinin kullanıldığı araştırmada sabit bekleme süreli öğretimin sayı sayma becerisinin öğretiminde etkili olduğu bulunmuştur. Sazak Pınar ve Kocabıyık (2014), orta düzeyde zihinsel yetersizliği olan öğrencilere örüntü oluşturma becerisinin öğretiminde doğrudan öğretim yönteminin etkililiğini incelemişlerdir. Çalışmaya 11-13 yaşlarında üç öğrenci katılmıştır. Denekler arası yoklama evreli çoklu yoklama modelinin kullanıldığı araştırma sonunda örüntü oluşturma becerisinin öğretiminde doğrudan öğretim yönteminin etkili olduğu görülmüştür. Berry (2007), yaptığı çalışmada toplama ve çıkarma işlemi becerisinin öğretiminde nokta belirleme tekniğinin etkililiğini araştırmıştır. Otizm tanısı almış on öğrenci bu araştırmanın katılımcılarını oluşturmuştur. Araştırma sonunda otizm tanısı almış öğrencilere toplama ve çıkarma işlemi becerisinin öğretiminde nokta belirleme tekniğinin etkili olduğu görülmüştür.

Yetersizliği olan bireylere günlük hayatlarında kullanabilecekleri matematiksel kavram ve becerilerin ögretimi sırasında öğretmenlere bazı sınıf içi görev ve sorumluluklar düşmektedir. Ayrıca yetersizliği olan bireylere öğretilecek matematiksel kavram ve becerilerin bu tür bireylerin yaşamını kolaylaştırdığı göz önüne alındığında öğretmenlerin matematik öğretimini yetersizliği olan bireylerin düzeylerini dikkate alarak bireyselleştirerek planlaması ve sunması gerektiği belirtilmektedir (Hudson ve Miller, 2006). Yetersizliği olan bireyler için bu denli önem arz eden matematiksel kavram ve becerilerin öğretimine gereken önemi vererek öğretim sırasında uygun yöntem teknikleri seçmeli ve kullanmalıdır (Alptekin, 2015). Matematiksel kavram ve becerilerin öğretimi sırasında öğretmenlere düşen görevlerden biri de konuya ve bireysel farklılıklar göz önüne alınarak yapılan uygun materyal seçimidir. Seçilen materyalin somut ve göze hitap etmesi tek başına bir anlam ifade etmemektedir (Stein ve Bovalino, 2001). Burada önemli olan öğretmenin seçtiği materyalin öğretilecek olan matematiksel kavram ve becerilerin özellikleriyle benzerlik göstermesidir (Hiebert ve Carpenter, 1992). Bu yüzden yetersizliği olan öğrencilerle çalışan öğretmenlerin materyal seçimine dikkat etmeleri gerektiği belirtilmektedir.

Yetersizliği olan bireylerle çalışan öğretmenler, öğrencilerin hedeflenen beceri ve kavramları öğrenip öğrenmediğini değerlendirmede çeşitli değerlendirme tekniklerini kullanması gerektiği; öğrencilerin ihtiyaç duyduğu matematiksel kavram ve becerileri iyi belirlemesi gerektiği belirtilmektedir (NCTM, 2000).

Alan yazın incelendiğinde farklı yetersizliğe sahip öğrencilere matematiksel kavram ve becerilerinin öğretildiği çalışmalara ulaşılmıştır. Fakat hafif düzeyde zihinsel yetersizliğine sahip öğrencilere matematiksel kavram ve becerilerinin öğretimine yönelik öğretmenlerin sınıf içi uygulamalarını belirleyen herhangi bir araştırmaya ulaşılamadığından, yapılan ve yapılacak olan çalışmalara katkı sağlayacağı düşünüldüğünden böyle bir araştırmanın yapılmasına ihtiyaç duyulmuştur. 
Zihinsel Yetersizliği Olan Öğrencilere Matematiksel Kavram ve Becerilerinin Öğretimine Yönelik Öğretmenlerin Sınıf İçi Uygulamalarının Belirlenmesi

Araştırmanın genel amacı; zihinsel yetersizliğe sahip öğrencilere matematiksel kavram ve becerilerinin ögretimine yönelik öğretmenlerin sınıflarında yaptıkları uygulamaları belirlemektir. Bu genel amaç doğrultusunda aşağıdaki sorulara yanıt aranmıştır.

Özel eğitim okulunda çalışan öğretmenler;

1. Matematik kavram ve becerilerini öğretirken öğretimin bireyselleştirilmesi bağlamında ne tür uyarlamalar yapmaktadırlar?

2. Öğrencilere öğretecekleri matematiksel kavram ve becerileri belirlerken nelere dikkat etmektedirler?

3. Öğrencilere matematik kavram ve becerilerinin öğretimi sürecinde ne tür zorluklar yaşamaktadırlar?

4. Öğretimi değerlendirme aşamasında neler yapmaktadırlar?

\section{YÖNTEM}

\section{Araştırma Modeli}

$\mathrm{Bu}$ araştırmada zihinsel yetersizliği olan öğrencilere matematiksel kavram ve becerilerin öğretilmesine yönelik özel eğitim okulunda çalışan öğretmenlerin sınıflarında yaptıkları uygulamaların belirlenmesi amaçlandığından nitel araştırma yöntemlerinden olgu bilim (fenomenoloji) deseninde yürütülmüştür. Olgu bilim deseni; kişilerin algılarını, yaşantı ve deneyimlerini derinlemesine bir yaklaşımla betimlemektedir (Yıldırım ve Şimşek, 2005). Yapılan araştırmada da özel eğitim öğretmenlerinin matematik kavram ve becerilerin öğretilmesine yönelik sınıflarında yaptıkları ve deneyimlerini ortaya çıkarmak için bu desen kullanılmıştır.

\section{Katılımcilar}

Araştırmanın bu bölümünde katılımcılara ilişkin demografik bilgilere yer verilmiştir. Araştırmada amaçlı örnekleme yöntemlerinden ölçüt örnekleme yöntemi kullanılarak katılımcılar belirlenmiştir. Yıldırım ve Şimşek'e (2008) göre ölçüt örnekleme yöntemi bir dizi ölçütü karşılayan tüm durumların çalışılması olarak tanımlanmaktadır. Bu araştırmada da öğretmenlerin en az üç yıl hafif düzey zihinsel yetersizliği olan öğrencilerle çalışma deneyimi olması, özel eğitime ilişkin seminer ya da kurs almış olması ve Milli Eğitim Bakanlığı bünyesinde çalışan okullarda görev yapıyor olması ölçüt olarak belirlenmiştir. Araştırmanın katılımcılarını özel eğitim okulunda çalışan öğretmenler oluşturmaktadır. Katılımcıların gerçek isimleri kullanılmayıp katılımcılara kod isim verilmiştir. Katılımcılara ilişkin demografik bilgilere Tablol'de yer verilmiştir.

Tablo1. Katılimcilartn demografik bilgileri

\begin{tabular}{|c|c|c|c|c|c|c|c|c|}
\hline Kod adı & Yaş & Cinsiyet & $\begin{array}{l}\text { Eŭitim } \\
\text { düzey }\end{array}$ & $\begin{array}{l}\text { M.olduğu } \\
\text { bölüm }\end{array}$ & $\begin{array}{l}\text { M.olduğu } \\
\text { Üniv. }\end{array}$ & Kidem & $\begin{array}{l}\text { Çalışma } \\
\text { süresi }\end{array}$ & $\begin{array}{l}\text { Seminer } \\
\text { ve } \\
\text { Kurslar }\end{array}$ \\
\hline Ekrem & 34 & $E$ & Lisans & Özel eğitim & $\begin{array}{l}\text { Anadolu } \\
\text { üniv. }\end{array}$ & $4 / 1$ & 11 & $\begin{array}{l}\text { İş sağlığı } \\
\text { ve } \\
\text { güvenliği }\end{array}$ \\
\hline Can & 33 & $\mathrm{E}$ & Lisans & Özel eğitim & $\begin{array}{l}\text { Ankara } \\
\text { üniv. }\end{array}$ & $4 / 2$ & 12 & $\begin{array}{l}\text { İş sağlığı } \\
\text { ve } \\
\text { güvenliği }\end{array}$ \\
\hline Fatoş & 34 & $\mathrm{~K}$ & Lisans & Özel eğitim & $\begin{array}{l}\text { Anadolu } \\
\text { üniv. }\end{array}$ & $5 / 1$ & 13 & $\begin{array}{l}\text { İş sağlığ } 1 \\
\text { ve } \\
\text { güvenliği }\end{array}$ \\
\hline Makbule & 35 & $\mathrm{~K}$ & Lisans & Özel eğitim & $\begin{array}{l}\text { Sakarya } \\
\text { üniv. }\end{array}$ & $4 / 2$ & 12 & $\begin{array}{l}\text { İş sağlığ } 1 \\
\text { ve } \\
\text { güvenliği }\end{array}$ \\
\hline Seher & 29 & $\mathrm{~K}$ & Lisans & $\begin{array}{l}\text { Sınıf } \\
\text { öğretmenliği }\end{array}$ & Uşak üniv. & $8 / 1$ & 4 & $\begin{array}{l}\text { İş sağlığı } \\
\text { ve } \\
\text { güvenliği }\end{array}$ \\
\hline İsmihan & 33 & $\mathrm{~K}$ & Lisans & $\begin{array}{l}\text { Sinıf } \\
\text { öğretmenliği }\end{array}$ & $\begin{array}{l}\text { Atatürk } \\
\text { ünv. }\end{array}$ & $8 / 2$ & 4 & 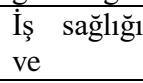 \\
\hline
\end{tabular}


Zihinsel Yetersizliği Olan Öğrencilere Matematiksel Kavram ve Becerilerinin Öğretimine Yönelik Öğretmenlerin Sınıf İçi Uygulamalarının Belirlenmesi

\begin{tabular}{|c|c|c|c|c|c|c|c|c|}
\hline & & & & & & & & güvenliği \\
\hline Deniz & 28 & K & Lisans & $\begin{array}{l}\text { Sinıf } \\
\text { öğretmenliği }\end{array}$ & $\begin{array}{l}\text { Sakarya } \\
\text { ünv. }\end{array}$ & $7 / 1$ & 4 & $\begin{array}{l}\text { İş sağliğ } \\
\text { ve } \\
\text { güvenliği }\end{array}$ \\
\hline Kiraz & 29 & K & Lisans & Özel eğitim & $\begin{array}{l}\text { Anadolu } \\
\text { ünv. }\end{array}$ & $6 / 2$ & 7 & $\begin{array}{l}\text { İş sağlığ } \\
\text { ve } \\
\text { güvenliği }\end{array}$ \\
\hline Eda & 47 & $\mathrm{~K}$ & Lisans & $\begin{array}{l}\text { Fransızca } \\
\text { öğretmenliği }\end{array}$ & $\begin{array}{l}\text { İstanbul } \\
\text { üniv. }\end{array}$ & $1 / 1$ & 25 & $\begin{array}{l}\text { İş sağliğ1 } \\
\text { ve } \\
\text { güvenliği } \\
\text { Özel } \\
\text { eğitim } \\
\text { kursu }\end{array}$ \\
\hline Erol & 37 & $\mathrm{E}$ & Lisans & Özel eğitim & Gazi üniv. & $5 / 2$ & 13 & $\begin{array}{l}\text { İş sağlığ } 1 \\
\text { ve } \\
\text { güvenliği }\end{array}$ \\
\hline
\end{tabular}

Tablo 1'de araştırmaya katılan öğretmenlerin demografik bilgileri incelendiğinde;.öğretmenler, Sakarya ilinin bir merkez ilçesinde hafif düzey zihinsel yetersizliği olan öğrencilerin bulunduğu Özel eğitim okulunda görev yapmaktadırlar. Özel eğitim okulunda çalışan öğretmenlerin çalışma süreleri 4 ile 25 yıl arasında değişmektedir. 3'ü erkek 7'si bayan olan katılımcıların altısı özel eğitim, üçü sınıf öğretmenliği ve bir öğretmen ise Fransızca öğretmenliği lisans programı mezunudur.

\section{Verilerin Toplanması ve Analizi}

Araştırmanın verileri Ekim-Aralık 2018 tarihleri arasında toplanmıştır. Araştırma verilerini toplamak için araştırmacılar tarafından alan yazın taranarak hazırlanan görüşme formu, özel eğitim alanında çalışan üç alan uzmanının görüşleri alınarak son hali verilmiştir. Görüşme formunda yer alan sorular alan uzmanları tarafindan hazırlanan soruların ele alınan konuyu kapsayıp kapsamadığı, soruların herkes tarafından açık ve net bir şekilde anlaşılır olup olmadığı göz önüne alınarak incelenmiştir. Özel eğitim alanında çalışan alan uzmanları tarafindan yapılan incelemeler neticesinde görüşme formunda yer alan sorular yeniden incelenerek son hali verilmiştir. Görüşme formunda aşağıdaki sorular yer almıştır:

1. Sınıfınızda matematiksel kavram ve becerilerini öğretirken öğretimin bireyselleştirilmesi bağlamında ne tür uyarlamalar yapıyorsunuz?

2. Matematik dersinde öğrencilerinizin dikkatini çekmeye ve sürdürmeye yönelik ne tür uygulamalar yapıyorsunuz?

3. Öğrencilerinize öğreteceğiniz matematik kavram ve becerileri belirlerken nelere dikkat ediyorsunuz?

4. Öğrencilere matematik kavram ve becerileri kazandırmada ne tür

a) materyallerden

b) yöntemlerden

c) teknolojilerden

d) etkinliklerden yararlanıyorsunuz?

5. Kullanacağınız öğretim yöntemlerini belirlerken nelere dikkat ediyorsunuz?

6. Öğrencilerinize matematik kavram ve becerilerinin öğretimi sürecinde ne tür zorluklar yaşadınız?

a) bunlara yönelik çözüm önerileriniz nelerdir?

7. Öğretimi değerlendirme aşamasında neler yapıyorsunuz?

Görüşme formunda yer alan soruların anlaşılır olup olmadığını ve belirlenen amaca hizmet edip etmediğini teyit etmek için özel eğitim okulunda çalışan bir öğretmenle ön görüşme yani pilot uygulama gerçekleştirilmiştir. Görüşme yapılmadan önce araştırmanın amacı öğretmene açıklanmış ve görüşmeler 
Zihinsel Yetersizliği Olan Öğrencilere Matematiksel Kavram ve Becerilerinin Öğretimine Yönelik Öğretmenlerin Sınıf İçi Uygulamalarının Belirlenmesi

sırasında ses kaydı yapılacağı belirtilmiştir. Yapılan ön görüşme neticesinde sorularda herhangi bir değişiklik yapılmamış ve diğer öğretmenlerle görüşmelere devam edilmiştir. Görüşmeye başlamadan önce araştırmacı kendini tanıtmış, görüşmenin amacını açıklayarak kaydın nasıl yapılacağını açıklamıştır. Görüşme başladığı andan itibaren ses kaydı açılarak veriler toplanmıştır. Görüşmeler ögretmenlerin görev yaptığı özel eğitim okulunda yapılmıştır. Görüşmeler yaklaşık 8 ile 15 dakika sürmüştür.

Özel eğitim okulunda çalışan öğretmenlerin, zihin yetersizliği olan öğrencilere matematiksel kavram ve becerilerinin öğretimine yönelik sınıflarında yaptıklarını belirlemek için hazırlanan sorulara vermiş oldukları cevaplar yazılı hale getirilmiştir. Yapılan deşifre işleminin güvenirliği dokümanların \%30 unda yapılmış ve \%100 olarak hesaplanmıştır. Bilgisayar ortamına verileri çözümlemek için ise betimsel analiz tekniği kullanılmıştır. Betimsel analiz tekniği ile veriler özetlenmiş ve yorumlanmıştır. Araştırmada öğretmenlerin işlevsel matematik kavram ve becerilerinin öğretimine yönelik sınıflarında yaptıklarını belirlemek için sorulan sorulara göre temalar oluşturulmuştur. Veriler de bu temalara göre oluşturularak analiz edilir. Katılımcılara kod adı verilerek görüşler aktarılmıştır. Araştırmada kullanılan sorular kategori olarak belirlenip söylenme sıklığı (frekans) dikkate alınarak tablolar oluşturulmuştur. Betimsel analizde katılımcının görüşlerini tam anlamıyla ortaya çıkarabilmek için doğrudan alıntılara yer verilir (Yıldırım ve Şimşek, 2008). Yapılan araştırmada da görüşmecilerin beyan ettikleri tırnak içinde söylenildiği gibi aktarılmıştır.

\section{Geçerlik ve Güvenirlik}

Araştırmada iç geçerliğe ilișkin görüşme formunda yer alan sorular, araștırmada elde edilen veriler ve verilerin yorumları uzman görüşüne sunulmuştur. Ayrıca iç geçerliği sağlamak adına araştırma sonunda elde edilen verilere ilişkin bulgular ve yorumlar katılımcıların \%25'ine (3 öğretmen) gösterilerek katılımcı onayı alınmıştır. Araştırmanın dış geçerliğine ilişkin ise araştırmaya katılan katılımcıların görüş bildirdiği cümlelerden örnekler verilerek doğrudan alıntılar tırnak içinde verilmiştir.

İç güvenirliği sağlamak için alan uzmanından araştırma verileri ve araştırmanın sonuçları arasında tutarlık incelemesi yapması istenmiştir. Alan uzmanı tarafından yapılan tutarlık incelemesi neticesinde analiz yaklaşımları ile araştırma verileri ve araştırma sonuçları arasında tutarlık olduğu saptanmıştır. Dış güvenirliği sağlamak için ise araştırmada elde edilen ham veriler ile verilere ilişkin sonuçlar ve bu verilere ilişkin yapılan yorumlar için alan uzmanının onayı alınmıştır.

\section{BULGULAR}

$\mathrm{Bu}$ bölümde Özel eğitim okulunda görev yapan öğretmenlerin matematik kavram ve becerilerin öğretimine yönelik sınıflarında yaptıklarını belirlemek için yapılan görüşmelerden elde edilen bulgulara yer verilmiştir. Elde edilen bulgular sorulara göre sıralanarak verilmiştir.

Özel eğitim okulunda çalışan öğretmenlerin matematiksel kavram ve becerilerin öğretimi sırasında sınıfta yaptıkları uyarlamalara yönelik bulgulara tablo 1'de yer verilmiştir.

Tablo1. Özel eğitim okulunda çalışan öğretmenlerin matematiksel kavram ve becerilerin öğretimi sirasında sinıfta yaptıkları uyarlamalara yönelik bulgular

\begin{tabular}{ll}
\hline Cevaplar & f \\
\hline Öğrencinin hazır bulunuşluk düzeyini belirlemek. & 10 \\
\hline Bireyselleştirilmiş eğitim planı hazırlamak. & 6 \\
\hline Bireysel öğretim yapmak. & 2 \\
\hline Bireyselleştirilmiş öğretim planı yapmak. & 2 \\
\hline Materyal uyarlaması yapmak. & 1 \\
\hline Kavram ve beceri uyarlaması yapmak. & 1 \\
\hline
\end{tabular}

Tablo1 incelendiğinde özel eğitim okulunda çalışan öğretmenler, matematiksel kavram ve becerilerin öğretimi sırasında öğrencilerin hazır bulunuşluk düzeyini belirledikleri, bireyselleştirilmiş eğitim ve öğretim planı yaptıklarını, öğrencilerle bireysel eğitim yaptıklarını, materyal ve kavram beceri uyarlaması yaptıklarını ifade etmişlerdir. Katılımcıların matematiksel kavram ve becerilerin öğretimi sırasında yaptıkları uyarlamalara ilişkin ifadeleri tırnak içerisinde aşağıda aynen aktarılmıştır. 
Zihinsel Yetersizliği Olan Öğrencilere Matematiksel Kavram ve Becerilerinin Öğretimine Yönelik Öğretmenlerin Sınıf İçi Uygulamalarının Belirlenmesi

Ö1. 'ilk başlarda en başta yaptığımız şey çocuğun hazır bulunuşluk düzeyini belirlemek yani performansinı almak'

Ö4. 'Bu bă̆lamda öğrencinin var olan performansını belirledikten sonra öğrenmesi gereken öncelikli beceriyi ele alvp uygun olan ögretim yöntemi ile bireysel öğretim gerçekleştirilmektedir'

Ö9: 'uyarlamalar...en başta öğrencilerin neleri bilip bilmediğini ölçmek amacıyla kaba değerlendirmelerini alıp buna göre beplerini hazırllyorum. Daha sonra kısa dönemli amaçları belirleyip ögrencilerin böplerini hazırlyyorum'

Özel eğitim okulunda çalışan öğretmenlerin matematiksel kavram ve becerilerin öğretimi sırasında öğrencilerin dikkatini çekmeye ve sürdürmeye yönelik yaptıkları uyarlamalara ilişkin bulgulara tablo 2'de yer verilmiştir.

Tablo2. Özel eğitim okulunda çalışan öğretmenlerin matematiksel kavram ve becerilerin ögretimi sırasında ögrencilerin dikkatini çekmeye ve sürdürmeye yönelik yaptıkları uygulamaya ilişkin bulgular

\begin{tabular}{ll}
\hline Cevaplar & f \\
\hline Dikkati çekmeye yönelik & \\
\hline Öğrencinin yakın çevresinden örnekler vermek. & 4 \\
\hline Konuyla ilgili materyal hazırlamak. & 2 \\
\hline Konuyu oyunlaştırmak. & 2 \\
\hline Konunun işlevsel olmasına dikkat etmek. & 2 \\
\hline Öğrencinin ilgi alanına göre problemler oluşturmak. & 1 \\
\hline Renkli kalemler kullanmak. & 1 \\
\hline Konuyla ilgili etkinlik hazırlamak. & 1 \\
\hline Aniden ses tonunda değişiklik yapmak. & 1 \\
\hline Şark1 söylemek. & 1 \\
\hline Konuyla ilgili hikaye anlatmak. & 1 \\
\hline Güncel konulardan bahsetmek. & 1 \\
\hline Dramadan faydalanmak. & 1 \\
\hline Sürdürmeye yönelik & $\mathbf{f}$ \\
\hline Dinlenmeleri için firsat vermek. & 1 \\
\hline Şaka yapmak. & 1 \\
\hline Fikra anlatmak. & 1 \\
\hline
\end{tabular}

Tablo2 incelendiğinde özel eğitim okulunda çalışan öğretmenler, matematiksel kavram ve becerilerin öğretimi sırasında öğrencilerin dikkatini çekmeye ve sürdürmeye yönelik öğrencinin yakın çevresinden örnekler verdiğini, konuyla ilgili materyal hazırladığını, konuyu oyunlaştırarak verdiğini, işlevsel konular seçtiğini, öğrencilerin ilgi alanlarına göre problem oluşturduğunu, renkli kalemler kullandıklarını, konuyla ilgili etkinlik hazırladıklarını, güncel konulardan bahsettiklerini, ders arasında dinlenmeleri için firsat verdiklerini, öğrencilerle şakalaştıklarını ve ders arasında fikra anlattıklarını ifade etmişlerdir. Katılımcıların matematiksel kavram ve becerilerin öğretimi sırasında öğrencilerin dikkatini çekmeye ve sürdürmeye yönelik yaptıkları uygulamaya ilişkin ifadeleri tırnak içerisinde aşağıda aynen aktarılmıştır.

Ö3. 'Matematik dersinde öğrencilerimin dikkatini çekmek için uı elimde varsa çeşitli malzemeler işte renkli kalemler, u onları kullanıyorum'

Ö5: 'eee genellikle eee yaparak yaşayarak öğretmeye çalışlyorum. Eee ondan sonra eee başka nasıl yapiim onları daha çok işin içine katmaya çalışlyorum. Materyallerden yararlanıyorum. ya ilk başladığımızda konumuz neyse onunla alakalı hikaye anlatıyorum. Veya gündelik yaşamdan örnekler veriyorum. Veya televizyonda o gün hani haberlerden veya güncel olaylardan onlarla ilgili bilgiler veriyorum,

Ö8: 'günlük hayatın içinden örnekler veririm. Öğrencilerin kendi günlük hayatlarından örnekler vermesini isterim. Özellikle problem çözerken ve dört işlem yaparken'

Ö9: 'öğrencilerin dikkatini çekmek amacıyla çeşitli dramalardan ve tahmin oyunları oynuyoruz’ 
Zihinsel Yetersizliği Olan Öğrencilere Matematiksel Kavram ve Becerilerinin Öğretimine Yönelik Öğretmenlerin Sınıf İçi Uygulamalarının Belirlenmesi

Özel eğitim okulunda çalışan öğretmenlerin matematiksel kavram ve becerileri belirlerken nelere dikkat ettiklerine yönelik bulgulara tablo 3'te yer verilmiştir.

Tablo3. Özel eğitim okulunda çalışan ögrretmenlerin matematiksel kavram ve becerileri belirlerken nelere dikkat ettiklerine yönelik bulgular

\begin{tabular}{ll}
\hline Cevaplar & f \\
\hline Öğrencinin hazır bulunuşluk düzeyi & 6 \\
\hline Kavram ve becerilerin işlevsel olması & 3 \\
\hline Ö̆ğrencinin bireysel farklılıkları & 3 \\
\hline Aile görüşleri & 1 \\
\hline
\end{tabular}

Tablo3 incelendiğinde özel eğitim okulunda çalışan öğretmenler, matematiksel kavram ve becerileri belirlerken öğrencinin hazır bulunuşluk düzeyini, kavram ve becerilerin işlevsel olmasını, öğrencinin bireysel farklılıklarını ve aile görüşlerini göz önünde bulundurduklarını belirtmişlerdir. Katılımcıların, matematiksel kavram ve becerileri belirlerken nelere dikkat ettiklerine ilişkin ifadeleri tırnak içerisinde aşağıda aynen aktarılmıştır.

Ö1. 'yani.. konuları belirlerken işte dediğimiz gibi öğrencilerin bulunduğu düzeye dikkat ediyoruz en fazla çocuğun hazır bulunuşluk düzeyine dikkat ediyoruz'

Ö3: 'çocuğumun performans düzeyine göre belirliyorum. Ki matematikte beceriler zincirleme diye düşünüyorum hepsi birbiriyle bağlantılı biri olmadan biri olmuyo. Toplama olmadan çarpma olmuyo gibi gibi gibi...ee performans düzeyine göre belirleyip devam ediyoruz'

Ö7: 'benim en çok dikkat ettiğim şey ee şu oluyo. Bunları gerçekten hayatlarında kullanabilecekleri kavram ve becerileri seçmeye çallşlyorum'

Ö9: ‘öğrencilerin günlük yaşamda kullanım oranlarını ve aile görüşlerini dikkate alıyorum’

Özel eğitim öğretmenlerinin matematiksel kavram ve becerileri kazandırmada kullandıkları materyallere, yöntemlere, teknolojilere ve etkinliklere yönelik bulgulara tablo 4'te yer verilmiştir.

Tablo4. Özel eğitim ögretmenlerinin matematiksel kavram ve becerileri kazandırmada kullandikları materyallere, yöntemlere, teknolojilere ve etkinliklere yönelik bulgular

\begin{tabular}{ll}
\hline Cevaplar & f \\
\hline Materyaller & \\
\hline Fotoğraf ve resimler & 3 \\
\hline Gerçek nesneler & 2 \\
\hline Somut materyaller & 2 \\
\hline Ders kitapları & 2 \\
\hline Resimli kartlar & 1 \\
\hline Soyut materyaller & 1 \\
\hline Dokulu materyaller & 1 \\
\hline Oyun hamurları & 1 \\
\hline Sayı oyunları & 1 \\
\hline Yazı tahtası & 1 \\
\hline Boş kağıtlar & 1 \\
\hline Defter & 1 \\
\hline Kalem & 1 \\
\hline Kaynak kitaplar + & 1 \\
\hline Yöntemler & $\mathbf{f}$ \\
\hline Doğrudan öğretim yöntemi & 8 \\
\hline Yaparak yaşayarak öğrenme & 3 \\
\hline İpucunun giderek azaltılması & 2 \\
\hline Model olma & 2 \\
\hline Eşzamanlı ipucuyla öğretim & 2 \\
\hline Basamaklandırılmış yöntem & 1 \\
\hline Buluş yoluyla öğretim & 1 \\
\hline Sabit bekleme süreli öğretim & 1 \\
\hline Akran öğretimi & 1 \\
\hline Teknolojiler & f \\
\hline Cep telefonu & 5 \\
\hline & \\
\hline
\end{tabular}


Zihinsel Yetersizliği Olan Öğrencilere Matematiksel Kavram ve Becerilerinin Öğretimine Yönelik Öğretmenlerin Sınıf İçi Uygulamalarının Belirlenmesi

\begin{tabular}{ll}
\hline Laptop & 3 \\
\hline Fotokopi makinesi & 2 \\
\hline Tabletler & 1 \\
\hline Bilgisayar yazılımı & 1 \\
\hline Akıllı tahta & 1 \\
\hline Etkinlikler & $\mathbf{f}$ \\
\hline Çalışma kağıtları & 4 \\
\hline Drama & 3 \\
\hline Oyun & 3 \\
\hline Hikayeleştirme & 2 \\
\hline
\end{tabular}

Tablo 4 incelendiğinde özel eğitim okulunda çalışan öğretmenler, matematiksel kavram ve becerileri kazandırmada fotoğraf ve resimler, gerçek nesneler, somut materyaller, ders kitapları, resimli kartlar, soyut materyaller, dokulu materyaller, oyun hamurları, sayı oyunları, yazı tahtası, boş kağıtlar, defter, kalem, kaynak kitaplar kullandıklarını; yöntemlerden, doğrudan öğretim yöntemi, yaparak yaşayarak öğrenme, ipucunun giderek azaltılması, model olma, eşzamanlı ipucuyla öğretim, basamaklandırılmış yöntem, buluş yoluyla öğretim, sabit bekleme süreli öğretim ve akran öğretimini, teknolojilerden; cep telefonu, laptop, fotokopi makinesi, tabletler, bilgisayar yazılımı ve akıllı tahta, etkinliklerden ise kendi hazırladıkları çalışma kağıtları, drama, oyun ve hikayeleştirmeyi kullandıklarını ifade etmişlerdir. Katılımcıların, matematiksel kavram ve becerileri kazandırmada kullandıkları materyallere, yöntemlere, teknolojilere ve etkinliklere ilişkin ifadeleri aşağıda tırnak içerisinde aynen aktarılmıştır.

Ö3: 'etkinlik kitaplarından faydalanıyorum eee işte sınıfimda olabildiği kadar ya da ulaşabildiğim kadar işte geometrik cisim gibi konular veriyorsam elimde olan materyallerden somut görsel materyallerden faydalanmaya çalışıorum'

Ö4. 'Gerçek nesneler, videolar, fotoğraf ve resimler, ögrenci ile birlikte hazırlayabildiğimiz dokulu materyaller'

Ö7: 'yani şöyle zaten sinıfta hali hazırda bulunan yazı tahtası başlıca en çok kullandığımız aslında yazı tahtası, çocukların kendi $u$ defterleri kalemleri $ı$ bunla beraber bizim o anda hazırladı̆̆ımız hızlı materyaller olabiliyo kă̆ıt üzerinde boş kağıtları çok sıklıkla kullanıyoruz. Yine bunla beraber önceden hazırladı̆̆ımı fotokopi materyaller kullanilabiliyo. Yine eee bunlara ek olarak işte alınan ufak tefek oyunlar sayı oyunları veya sayı küpleri'

Ö3: 'doğrudan öğretim yöntemini çok fazla kullaniyorum. Aynen o yöntemi tercih ediyorum. Yüzde doksaninda diyebilirim'

Ö4. 'Yaparak yaşayarak öğrenme, doğrudan öğretim, ip ucunun azaltılmast ve hikayeleştirme'

Ö8: 'daha çok eee internetten, cep telefonundan ve fotokopi makinasindan yararlaniyorum'

Özel eğitim okulunda çalışan öğretmenlerin kullanacakları öğretim yöntemini belirlemeye yönelik ifadelerini kapsayan bulgulara tablo 5'te yer verilmiştir.

Tablo5. Özel eğitim okulunda çalışan öğretmenlerin kullanacakları öğretim yöntemini belirlemeye yönelik ifadelerini kapsayan bulgular

\begin{tabular}{ll}
\hline Cevaplar & f \\
\hline Öğrencinin performans düzeyi & 7 \\
\hline Öğrenci ilgisi & 2 \\
\hline Öğrencinin bireysel özellikleri & 2 \\
\hline Öğrencinin bireysel yetersizlikleri & 1 \\
\hline
\end{tabular}

Tablo5 incelendiğinde özel eğitim okulunda çalışan öğretmenler kullanacakları yöntemleri belirlerken öğrencinin performans düzeyini, öğrencilerin ilgilerini, öğrencinin bireysel özelliklerini ve yetersizliklerini dikkate aldıklarını belirtmişlerdir. Katılımcıların, kullanacakları öğretim yöntemini belirlemeye ilişkin ifadeleri aşağıda tırnak içerisinde aynen aktarılmıştır.

Ö1. 'ul çocuğumuzun dediğimiz gibi durumuna dikkat ediyorum u öğrencimizin durumu bu konuda bize hani yöntem konusunda ee bir fikir veriyo. Performans düzeyi çocuğumuzun performans 
Zihinsel Yetersizliği Olan Öğrencilere Matematiksel Kavram ve Becerilerinin Öğretimine Yönelik Öğretmenlerin Sınıf İçi Uygulamalarının Belirlenmesi

düzeyi seçeceğimiz yöntem konusunda bir fikir veriyo. Hani o çocuğun durumuna göre hangi yöntemleri daha çabuk ilerleriz hangi yöntem daha etkili olur ona göre bir seçim yapılabilir diye düşünüyorum'

Ö2: 'çocuğu ,çocuğa uygun olması temel kistasım bu performans düzeyi'

Ö6: 'burda da yine öğrencilerin ilgilerine göre karar veriyorum yani ilgisini çeken ee durumlar nasılsa ona göre yöntem belirliyorum. Ee yine ee ögrencilerin işte anlama düzeylerine göre de yöntemleri belirliyorum yani'

Ö7: 'kullanıcam öğretim yöntemleri ee bikere çocukların bireysel yetersizlikleri öncelikle ee dikkat ediyoruz'

Özel eğitim öğretmenlerinin matematiksel kavram ve becerilerin öğretimi sürecinde yaşadıkları zorluklara ve çözüm önerilerine yönelik bulgulara tablo 6'da yer verilmiştir.

Tablo6. Özel ĕgitim öğretmenlerinin matematiksel kavram ve becerilerin öğretimi sürecinde yaşadıkları zorluklara ve çözüm önerilerine yönelik bulgular

\begin{tabular}{ll}
\hline Cevaplar & f \\
\hline Yaşanılan zorluklar & \\
\hline Materyal eksikliği & 4 \\
\hline Bilgiyi somutlaştırma & 3 \\
\hline Öğrenci dikkatinin dağılması & 3 \\
\hline Ŏğrenci düzeyinin farklı olması & 2 \\
\hline Ön koşul becerilerin unutulması & 2 \\
\hline Öğrencinin hazır bulunuşluk düzeyinin yetersiz olması & 1 \\
\hline Bilgiyi genellemede & 1 \\
\hline Öğrenilen kavram ve becerinin karıştırılması & 1 \\
\hline Öğrencinin bilgiyi hatırlamaması & 1 \\
\hline Çözüm önerileri & $\mathbf{f}$ \\
\hline Sik tekrarın yapılması & 5 \\
\hline Dikkat arttırıcı materyallerin olması & 4 \\
\hline Erken eğitim & 1 \\
\hline Okul ve sınıfların donanımlı olması & 1 \\
\hline Verilen ödevlerin aile kontrolünde yapılması & 1 \\
\hline Aile ile işbirliği & 1 \\
\hline Eğitimin bire bir verilmesi & 1 \\
\hline
\end{tabular}

Tablo 6 incelendiğinde özel eğitim okulunda çalışan öğretmenler, materyal eksikliği, bilgiyi somutlaştırmada, öğrenci dikkatinin dağılması, öğrenci düzeyinin farklı olması, ön koşul becerilerin unutulması, öğrencinin hazır bulunuşluk düzeyinin yetersiz olması, bilgiyi genellemede, öğrenilen kavram ve becerinin karıştırılması ve öğrencinin bilgiyi hatırlamamasında zorluk yaşadıklarını; bu zorlukların üstesinden gelmek için ise öğretilen konunun sk tekrarının yapılması gerektiği, dikkat arttırıcı materyallerin kullanılması, öğrencilerin erken eğitime başlaması gerektiği, okul ve sınıfların donanımlı olması, verilen ödevlerin aile kontrolünde yapılması ve eğitimin bire bir verilmesi gerektiğini ifade etmişlerdir. Katılımcıların, özel eğitim öğretmenlerinin matematiksel kavram ve becerilerin öğretimi sürecinde yaşadıkları zorluklara ve çözüm önerilerine yönelik ifadeleri aşağıda tırnak içerisinde aynen aktarılmıştır.

Ö1. 'aooo zorluklar mesela şöyle bir zorluk olabilir. yaşadığımız en belirgin olarak bilgiyi başka bir alana transfer etmede zorluk yaşlyoruz'

Ö2: 'soyut kavramların somutlaştırılmasında bi güçlük yaşıyoruz'

Ö7: 'materyallerle ilgili eksikliklerimiz çok oluyo. Her zaman materyal bulamayabiliyoruz. Kırtasiye malzemeleriyle ilgili eksiklikler yaşıyoruz. Ee bunla beraber grup içi çocukların seviyeleri birbirine çok yakın olmadı̆̆ için eee aynı konuyu anlatırken çocuk çok ilgisiz kalabiliyo' 
Zihinsel Yetersizliği Olan Öğrencilere Matematiksel Kavram ve Becerilerinin Öğretimine Yönelik Öğretmenlerin Sınıf İçi Uygulamalarının Belirlenmesi

Ö8: 'mateamatik soyut bie ders olduğu için onunla ilgili olan soyut kavramlart somutlaştırmada zorluk yaşıyoruz. Öğrencinin ögrenmiş olduğu bir bilgiyi hatırlamasında ve materyal bulmada zorluklar yaşanabiliyo'

Çözüm önerilerine yönelik ise;

Ö3: 'okullarımızın sinıflarımızın donanım, teknolojik anlamda materyal anlamında görsel özellikle bizim çocuklarımızın görsel ürünlere çok fazla ihtiyact var. Eee bence bunlara kesinlikle temin edilmeli fazlasiyla bu kadar'

Ö4. 'Sık sık konu tekrarı, verilen ödevlerin ailenin kontrolünde yapılmış olması yani ev tekrarları çok önemli’

Ö8: ‘ögrrenciye sık sık tekrar yaptırmak. Özellikle dört işlem ve problem çözmede somut nesneler ve materyaller kullanarak sorunları aşabiliriz diye düşünüyorum...’

Ö9: 'Eski ve yeni davranışların bol tekrar ile desteklenmesi'

Ö10: ‘̋̈grenciye sik sik tekrar yaptırmak. Konularla ilgili materyaller bulursak ve temin edilirse ögrenci bire bir gerçek nesnelerle konuyu daha rahat öğrenir’ İfade etmişlerdir.

Özel eğitim öğretmenlerinin öğretimi değerlendirme aşamasında yaptıklarına yönelik bulgulara tablo 7 'de yer verilmiştir.

Tablo7. Özel ĕgitim öğretmenlerinin öğretimi dĕgerlendirme aşamasında yaptıklarına yönelik bulgular

\begin{tabular}{ll}
\hline Cevaplar & f \\
\hline Değerlendirme testi & 3 \\
\hline Yazılı yoklama & 3 \\
\hline Yoklama oturumları düzenleme & 2 \\
\hline Ölçüt bağımlı ölçü aracı kullanma & 1 \\
\hline Kaba değerlendirme formuna göre değerlendirme & 1 \\
\hline Sözlü olarak değerlendirme & 1 \\
\hline Ölçüt belirleme & 1 \\
\hline
\end{tabular}

Tablo7 incelendiğinde özel eğitim okulunda çalışan öğretmenler öğretimi değerlendirme aşamasında, öğretim sonunda öğrencilere değerlendirme testi verdikleri, yazılı yoklama yaptıkları, yoklama oturumları düzenlediklerini, ölçüt bağımlı ölçü aracı kullandıklarını, kaba değerlendirme formuna göre değerlendirme yaptıklarını, sözlü olarak değerlendirme yaptıklarını ve ölçüt belirlediklerini ifade etmişlerdir. Katılımcıların, öğretimi değerlendirme aşamasında yaptıklarına yönelik ifadeleri aşağıda tırnak içerisinde aynen aktarılmıştır.

Ö5: 'şimdi öğretimi değerlendirme aşamasında şöyle yapıyorum kazandırdığım davranışı çocuğun öğrenip öğrenmediğini anlamak için uygulama çalışmast yapıyorum'

Ö7: 'eee öğretim değerlendirme aşamasında çocuğun zaten en başta kaba değerlendirmesini aldiğımızda ee yine ara değerlendirmeler yapıyoruz koyduğumuz hedeflere yönelik yani aşağ yukarı aylık ara değerlendirmeler ee bu ara değerlendirmeler çocuk artık ee ne kadar bağımsız yerine getirebiliyo benim kavram ve beceri koyduğum kavram ve beceri hedeflerini buna bakıyorum'

Ö8: 'eee konu ile ilgili sorulan soruyu herhangi bir ipucu olamadan ve alamadan ögrencinin bağımsız olarak cevaplandırmasını istiyorum. Bireysel konuyla ilgili etkinlikler ve sorular veriyorum ögrencilere. Bu soruları bağımsız yapmasını istiyorum' yapıyorum'

Ö9: 'konuyu ögrettikten sonra kazanıp kazanmadığını ölçmek için değerlendirme testi

Ö10: 'eee konu ile ilgili sorulan sorulara sözlü olarak cevap vermelerini istiyorum ve tabi ki konuyla ilgili değerlendirme testleri uyguluyorum' 
Zihinsel Yetersizliği Olan Öğrencilere Matematiksel Kavram ve Becerilerinin Öğretimine Yönelik Öğretmenlerin Sınıf İçi Uygulamalarının Belirlenmesi

\section{TARTISSMA ve SONUÇ}

Zihinsel yetersizliği olan öğrencilere matematiksel kavram ve becerilerinin öğretimine yönelik özel eğitim okulunda çalışan öğretmenlerin sınıflarında yaptı̆̆ uygulamaların belirlendiği araştırmanın ilk bulgusu incelendiğinde özel eğitim okulunda çalışan öğretmenler, zihinsel yetersizliği olan öğrencilere matematiksel kavram ve becerilerin öğretiminin bireyselleştirilmesi bağlamında öğrencilerin hazır bulunuşluk düzeylerini belirledikleri, bireyselleştirilmiş eğitim ve öğretim planı yaptıklarını, öğrencilerle bireysel eğitim yaptıklarını, materyal ve kavram beceri uyarlaması yaptıklarını ifade etmişlerdir. Hacısalihoğlu-Karadeniz (2017) yürüttüğü çalışmasında okullarda yapılan kaynaştırma eğitiminde matematik uygulamasına gitmeden önce yapılan hazırlık aşamalarına ilişkin öğretmen adaylarının vermiş olduğu ifadelerle örtüşmektedir. Öğretim yapılmadan önce öğrencinin hazır bulunuşluk düzeyini belirlemeye yönelik yapılan uygulamalar, öğrencilerin öğretilecek konuya dair neleri bilip neleri bilmediğini belirlemek adına önemli görülmektedir. Daha sonra öğrencinin performans düzeyine göre hazırlanacak olan bireyselleştirilmiş eğitim ve öğretim planlarıyla öğrencinin küçük ve emin adımlarla ilerlemesine fayda sağlayacağı için her öğrencinin düzeyine uygun hazırlanan bireyselleştirilmiş eğitim planlarının önemli olduğu düşünülmektedir.

Araştırmada elde edilen veriler arasında matematik kavram ve becerilerin öğretimi sırasında özel eğitim okulunda çalışan öğretmenlerin, öğrencilerin dikkatini çekmeye ve sürdürmeye yönelik farklı düşünceleri olduğu görülmektedir. Öğretmenler, öğrencilerin dikkatini çekmeye ve sürdürmeye yönelik öğrencinin yakın çevresinden örnekler verdiğini, konuyla ilgili materyal hazırladığını, konuyu oyunlaştırarak verdiğini, işlevsel konular seçtĭgini, öğrencilerin ilgi alanlarına göre problem oluşturduğunu, renkli kalemler kullandıklarını, konuyla ilgili etkinlik hazırladıklarını, güncel konulardan bahsettiklerini, ders arasında dinlenmeleri için firsat verdiklerini, öğrencilerle şakalaştıklarını ve ders arasında fikra anlattıklarını ifade etmişlerdir. Bu araştırmanın bulgularıyla Erbaş'ın (2008) çalışmasının bulguları paralellik göstermektedir. Normal gelişim gösteren öğrencilere kıyasla zihin yetersizliği olan ögrenciler dikkatlerini toplamada ve sürdürmede sıkıntı yaşadıkları bilinmektedir. $\mathrm{Bu}$ açıdan bakıldığında öğretmen derse başlamadan önce ve ders esnasında öğrencilerin dağılan dikkatlerini etkinlik üzerine çekmeleri öğrencilerin verilen konuyu öğrenmeleri ve etkinlik esnasında sıkılmamaları açısından önemli görülmektedir.

Yapılan görüşmeler neticesinde öğretmenler, matematik kavram ve becerileri belirlerken öğrencinin hazır bulunuşluk düzeyini, kavram ve becerilerin işlevsel olmasını, öğrencinin bireysel farklılıklarını ve aile görüşlerini göz önünde bulundurduklarını belirtmişlerdir. Öğrenci performanslarının matematik kavram ve becerilerini seçerken dikkate alınması ve bu sürece ailenin de dahil edilmesi bu süreci kolaylaştıracağı söylenebilir. Ailenin görüşlerinin alınması ve seçilecek olan kavram becerileri öğrencinin günlük hayatında kullanabilecek olması bu becerilerin önemli olduğuna işaret etmektedir.

Araştırmanın bir diğer bulgusu ise, öğretmenlerin matematik kavram ve becerileri öğrencilere kazandırırken sınıflarında kullandıkları materyal, yöntem, teknoloji ve etkinliklere yönelik olmasıdır. Matematik kavram ve beceri öğretiminin kalıcı olabilmesi için bu tür kavram ve becerilerin öğrenci performansına ve hazır bulunuşluk düzeyine göre verilmesi gerektiği belirtilmektedir (Gürsel ve Yıımış, 2001). Araştırmanın bulguları incelendiğinde özel eğitim okulunda çalışan öğretmenler, matematik kavram ve becerileri kazandırmada fotoğraf ve resimler, gerçek nesneler, somut materyaller, ders kitapları, resimli kartlar, soyut materyaller, dokulu materyaller, oyun hamurları, sayı oyunları, yazı tahtası, boş kağıtlar, defter, kalem, kaynak kitaplar kullandıklarını; yöntemlerden, doğrudan öğretim yöntemi, yaparak yaşayarak öğrenme, ipucunun giderek azaltılması, model olma, eşzamanlı ipucuyla öğretim, basamaklandırılmış yöntem, buluş yoluyla öğretim, sabit bekleme süreli öğretim ve akran öğretimini, teknolojilerden; cep telefonu, laptop, fotokopi makinesi, tabletler, bilgisayar yazılımı ve akıllı tahta, etkinliklerden ise kendi hazırladıkları çalışma kağıtları, drama, oyun ve hikayeleştirmeyi kullandıklarını ifade etmişlerdir. Vural ve Yıkmış'ın (2008) yapmış oldukları çalışmada da benzer sonuçlara ulaşılmıştır. Yürüttükleri araştırmada kaynaştırma sınıfı öğretmenlerinin sınıflarında sorucevap, dramatizasyon, yaparak yaşayarak öğretim yöntemi ve demonstrasyon yöntemini sıklıkla kullandıkları görülmektedir. Bu açıdan bakıldığında Vural ve Yıkmış'ın (2008) yapmış olduğu çalışmanın bulguları bu araştırmanın bulgularını destekler niteliktedir. 
Zihinsel Yetersizliği Olan Öğrencilere Matematiksel Kavram ve Becerilerinin Öğretimine Yönelik Öğretmenlerin Sınıf İçi Uygulamalarının Belirlenmesi

Öğretmenlerin materyalleri ve etkinlikleri belirlerken öğrencilerin seviyesine uygun olması, materyallerin göze hitap etmesi ve dikkat çekici olması, belirlenen hedef ve amaçlara uygun olması materyallerin öğretim sürecinde etkili olması bakımından önemli olduğu düşünülmektedir.

Özel eğitim okulunda çalışan öğretmenlerin, matematiksel kavram ve becerilerinin öğretimi sürecinde materyal eksikliği, bilgiyi somutlaştırmada, öğrenci dikkatinin dağılması, öğrenci düzeyinin farklı olması, ön koşul becerilerin unutulması, öğrencinin hazır bulunuşluk düzeyinin yetersiz olması, bilgiyi genellemede, öğrenilen kavram ve becerinin karıştırılması ve öğrencinin bilgiyi hatırlamamasında zorluk yaşadıklarını ifade etmeleri araştırmanın diğer bulgularından biridir. $\mathrm{Bu}$ açıdan incelendiğinde Hacısalihoğlu-Karadeniz'in (2017) yapmış olduğu araştırmanın bulgularıyla paralellik göstermektedir. Yukarıda sayılan zorlukların üstesinden gelmek ya da yaşanılan bu tür zorlukları en az seviyeye çekmek için öğretilen konuların sık tekrarının yapılması, dikkat arttırıcı materyallerin kullanılması, öğrencilerin mümkün olduğunca erken eğitime başlamaları, okul ve sınıfların gerekli araç gereçlerle donatılması önerilebilir.

Araştırmanın son bulgusu ise özel eğitim okulunda çalışan öğretmenlerin matematiksel kavram ve becerileri değerlendirme aşamasında neler yaptıklarıdır. Erdal ve Halat'a (2009) göre sınıf öğretmenlerinin en çok tercih ettiği ve öğretimi değerlendirme aşamasında kullandıkları ölçme araçları yazılı sınav, çoktan seçmeli sınav, proje ödevleri, öz değerlendirme, akran değerlendirmesi, öğrenci günlükleri ve kavram haritalarıdır. Bu araştırmada ise öğretmenlerin matematik kavram ve becerilerin öğretimini değerlendirme aşamasında öğrencilere değerlendirme testi verdikleri, yazılı yoklama yaptıkları, yoklama oturumları düzenlediklerini, ölçüt bağımlı ölçü aracı kullandıklarını, kaba değerlendirme formuna göre değerlendirme yaptıklarını, sözlü olarak değerlendirme yaptıklarını ve ölçüt belirlediklerini ifade ettikleri görülmektedir. Bu açıdan bakıldığında özel eğitim okulunda çalışan öğretmenlerin öğretimi değerlendirme aşamasında daha farklı yöntemleri kullanmasının özel eğitimde her öğrencinin bireysel olarak değerlendirilmesine dayandırılabilir. Bu araştırma verilerinin Erdal ve Halat'ın (2009) yapmış olduğu araştırmadan farklılaşması buna bağlanabilir.

Sonuç olarak matematiksel kavram ve becerilerin öğretimi sırasında özel eğitim okulunda çalışan öğretmenler, öğrencilerin hazır bulunuşluk düzeyini belirledikleri, bireyselleştirilmiş eğitim ve öğretim planı yaptıklarını, öğrencilerle bireysel eğitim yaptıklarını, materyal ve kavram beceri uyarlaması yaptıklarını ifade etmişlerdir. Matematiksel kavram ve becerilerin öğretimi sırasında öğrencilerin dikkatini çekmeye ve sürdürmeye yönelik öğrencinin yakın çevresinden örnekler verdiğini, konuyla ilgili materyal hazırladığını, konuyu oyunlaştırarak verdiğini, işlevsel konular seçtiğini, öğrencilerin ilgi alanlarına göre problem oluşturduğunu, renkli kalemler kullandıklarını, konuyla ilgili etkinlik hazırladıklarını, güncel konulardan bahsettiklerini, ders arasında dinlenmeleri için firsat verdiklerini, öğrencilerle şakalaştıklarını ve ders arasında fikra anlattıklarını ifade etmişlerdir. Öğretmenler, matematiksel kavram ve becerileri belirlerken öğrencinin hazır bulunuşluk düzeyini, kavram ve becerilerin işlevsel olmasını, öğrencinin bireysel farklılıklarını ve aile görüşlerini göz önünde bulundurduklarını belirtmişlerdir. Bu tür becerileri kazandırmada fotoğraf ve resimler, gerçek nesneler, somut materyaller, ders kitapları, resimli kartlar, soyut materyaller, dokulu materyaller, oyun hamurları, sayı oyunları, yazı tahtası, boş kağıtlar, defter, kalem, kaynak kitaplar kullandıklarını; yöntemlerden, doğrudan öğretim yöntemi, yaparak yaşayarak öğrenme, ipucunun giderek azaltılması, model olma, eşzamanlı ipucuyla öğretim, basamaklandırılmış yöntem, buluş yoluyla öğretim, sabit bekleme süreli öğretim ve akran öğretimini, teknolojilerden; cep telefonu, laptop, fotokopi makinesi, tabletler, bilgisayar yazılımı ve akıllı tahta, etkinliklerden ise kendi hazırladıkları çalışma kağıtları, drama, oyun ve hikayeleştirmeyi kullandıklarını ifade etmişlerdir. Öğretmenler, kullanacakları yöntemleri belirlerken öğrencinin performans düzeyini, öğrencilerin ilgilerini, öğrencinin bireysel özelliklerini ve yetersizliklerini dikkate aldıklarını belirtmişlerdir.

Özel eğitim okulunda çalışan öğretmenler, materyal eksikliği, bilgiyi somutlaştırmada, öğrenci dikkatinin dağılması, öğrenci düzeyinin farklı olması, ön koşul becerilerin unutulması, öğrencinin hazır bulunuşluk düzeyinin yetersiz olması, bilgiyi genellemede, öğrenilen kavram ve becerinin karıştırılması ve öğrencinin bilgiyi hatırlamamasında zorluk yaşadıklarını; bu zorlukların üstesinden gelmek için ise ögretilen konunun sık tekrarının yapılması gerektiği, dikkat arttırıcı materyallerin kullanılması, 
Zihinsel Yetersizliği Olan Öğrencilere Matematiksel Kavram ve Becerilerinin Öğretimine Yönelik Öğretmenlerin Sınıf İçi Uygulamalarının Belirlenmesi

öğrencilerin erken eğitime başlaması gerektiği, okul ve sınıfların donanımlı olması, verilen ödevlerin aile kontrolünde yapılması ve eğitimin bire bir verilmesi gerektiğini ifade etmişlerdir. Öğretimi değerlendirme aşamasında ise, öğretim sonunda öğrencilere değerlendirme testi verdikleri, yazılı yoklama yaptıkları, yoklama oturumları düzenlediklerini, ölçüt bağımlı ölçü aracı kullandıklarını, kaba değerlendirme formuna göre değerlendirme yaptıklarını, sözlü olarak değerlendirme yaptıklarını ve ölçüt belirlediklerini ifade etmişlerdir.

\section{ÖNERILER}

Yapılan araştırma, çalışmaya katılan katılımcılarla, zihin yetersizliği olan öğrencilere matematik kavram ve becerilerin öğretilmesine yönelik öğretmenlerin sınıfta yaptıkları uygulama ve uyarlamaları belirlemek için hazırlanan yarı yapılandırılmış görüşme sorularıyla sınırlıdır. Bu bulgular ışığında; Daha çok katılımcıyla nicel bir araştırma planlanabileceği, özel eğitim öğretmenlerinin sınıflarında gerekli düzenleme ve uyarlamaları yapabilmeleri için hizmet içi eğitim almaları sağlanabileceği, matematiksel kavram ve becerileri kazandırmada öğretmenlere materyal desteği sağlanabileceği, farklı yetersizlik türüne sahip öğrencilerle çalışan öğretmenlerin araştırılan konuya ilişkin görüşleri alınabileceği önerilebilir.

\section{KAYNAKÇA}

Akmanoğlu, N. (2002). Otistik bireylere adı söylenen rakamı seçme becerisinin öğretiminde eşzamanlı ipucunun etkililiği. Yayımlanmamış yüksek lisans tezi. Anadolu Üniversitesi Eğitim Bilimleri Enstitüsü, Eskişehir.

Alptekin, S. (2015). Sayma becerilerinin öğretimi. Ankara Üniversitesi Ĕ̆itim Bilimleri Fakültesi Özel Eğitim Dergisi, 16(1), 63-72.

Baykul, Y., ve Aşkar, P. (1987). Özel ögretim yöntemleri-matematik öğretimi. Eskişehir: Anadolu Üniversitesi Açı Öğretim Fakültesi Yayınları.

Baykul, Y. (2016). Illkokulda matematik ögretimi. Ankara: Pegem Akademi.

Berry, D. (2007). The effectiveness of the touchmath curriculum to teach addition and subtraction to elementary aged students identified with autism. 10 Haziran 2019 tarihinde http://www.touchmath.com/pdf/TouchmathAutism.pdf adresinden erişildi.

Cawley, J. F. \& Miller, J. H. (1989). Cross-sectional comparisons of the mathematical performance of children. Journal of Learning Disabilities, 22(4), 250-254, 259.

Performance Of Children With Learning Disabilities: Are we on the right track toward comprehensive programming? Journal of Learning Disabilities, 22(4), 250-259.

Calhoon, M. B., \& Fuchs, L. S. (2003). The effects of peer-assisted learning strategies and curriculumbased measurement on the mathematics performance of secondary students with disabilities. Remedial and Special Education, 24(4), 235-245.

Daugherty, S., Grisham-Brown, J., \& Hemmeter, M. L. (2001). The effects of embedded skill instruction on the acquisition of target and nontarget skills in preschoolers with developmental delays. Topics in Early Childhood Special Education, 21(4), 213-221.

Durmuş, S., ve Yıkmış, A. (2004). Matematikte öğrenme güçlüğü yaşayan ögrencileri tanımaya yönelik bir çalışma. 14th. National Special Education Congress. Bolu, Turkey.

Eldeniz-Çetin. M., ve Çay, E. (2016). Zihinsel yetersizliği olan öğrencilere bowling becerisinin öğretiminde eşzamanlı ipucuyla öğretimin etkililiği. Sosyal Bilimler Dergisi, 3(9), 441-455.

Eliçin, Ö., Dağseven Emecen, D., ve Yıkmış, A. (2013). Zihin engelli çocuklara doğrudan öğretim yöntemiyle temel toplama işlemlerinin öğretiminde nokta belirleme tekniği kullanılarak yapılan öğretimin etkinliği. M. Ü. Atatürk Eğitim Fakültesi Eğitim Bilimleri Dergisi, 37, 118-136. 
Zihinsel Yetersizliği Olan Öğrencilere Matematiksel Kavram ve Becerilerinin Öğretimine Yönelik Öğretmenlerin Sınıf İçi Uygulamalarının Belirlenmesi

Erbaş, D. (2008). Özel gereksinimli öğrencilere genel para kullanımı öğretme. Ankara Üniversitesi Eğitim Bilimleri Fakültesi Özel Ĕ̈itim Dergisi, 9(1) 35-52.

Eripek, S. (2003). Zeka geriliği olan çocuklar. A. Ataman (Ed.) Özel Gereksinimli Çocuklar ve Özel Eğitime Giriş içinde (153-173). Ankara: Gündüz Eğitim ve Yayınc1lık.

Erdal, E., ve Halat. H. (2009). Sinıf ögretmenlerinin matematik dersinde kullandıkları ölçme araçları ve ölçme araçlar ile ilgili bilgi düzeyleri. XVI Ulusal Eğitim Bilimleri Kongresi. Gaziosmanpaşa Üniversitesi, Tokat, Türkiye

Fuchs, L. S., \& Fuchs, D. (2005). Enhancing mathematical problem solving for students with disabilities. The Journal of Special Education, 39(1), 45-57.

Gürsel, O. (2010). Matematik öğretimi. İbrahim H Dikmen (Ed.), İlköğretimde kaynaştırma içinde (s. 444). Ankara: Pegem Yayın Evi

Gürsel, O. ve Yıkmış A. (2001). Engelli çocuklara matematik becerilerinin kazandırılmasında öğretmen ve öğrenci etkileşiminin basamaklandırılması. Abant İzzet Baysal Üniversitesi, Sosyal Bilimler Enstitüsü Dergisi, 2, 23-30.

Hacısalihoğlu Karadeniz, M.(2017).Öğretmen adaylarının özel eğitim ve kaynaştırma eğitiminde matematik uygulamalarına ilişkin görüşleri. Kalem Uluslararası Eğitim ve İnsan Bilimleri Dergisi. 7(1), 119-158.

Hiebert, J. \& Carpenter, T. P. (1992). Learning and teaching with understanding. In D. A. Grouws (Ed.), Handbook of research on mathematics teaching and learning, (pp. 65-97). New York: Macmillan.

Hudson, P. \& Miller, S. P. (2006). Designing and implementing mathematics instruction for students with diverse leaming needs. Boston: Pearson Education Inc.

Katlav-Önal, Z. (2008). Akran öğrenciler desteği ile sunulan sabit bekleme süreli öğretimin genel eğitim sınıflarında eğitim gören özel gereksinimli ögrencilerin çıkarma işlemini kazanmalarındaki etkililiğinin incelenmesi. Yayımlanmamış yüksek lisans tezi. Ankara Üniversitesi Eğitim Bilimleri Enstitüsü, Ankara.

Karabulut, A. ve Yıkmış A. (2010). Zihin engelli bireylere saat söyleme becerisinin öğretiminde eşzamanlı ipucuyla öğretimin etkililiği. Abant İzzet Baysal Üniversitesi Ĕgitim Fakültesi Dergisi 10(2), 103-113.

Krosbergen, E. H., \& Van-Luit, J. E. H. (2003). Mathematics interventions for children with special educational needs: A meta-analysis. Remedial and Special Education, 24(2), 97-114.

Kot, M. (2014). Zihinsel yetersizliği olan öğrencilere problem çözme becerisinin öğretiminde şemaya dayalı ögretim stratejisinin etkililiği. Yayınlanmamış yüksek lisans tezi. Abant İzzet Baysal Üniversitesi, Eğitim Bilimleri Enstitüsü, Bolu.

Kot, M., Sönmez, S., Yıkmış, A., ve Cora İnce, N. (2016). İşitme yetersizliği olan öğrencilere eldeli toplama işlemi öğretiminde nokta belirleme tekniğinin etkililiği. Current Research in Education, 2(1), 17-28.

Kot, M., Sönmez, S., ve Yıkmış, A. (2017). Zihinsel yetersizliği olan öğrencilere toplama işlemi öğretiminde doğrudan öğretim yöntemiyle sunulan nokta belirleme tekniği ile sayı doğrusu stratejisinin karşılaştırılması. Ankara Üniversitesi Ĕ̈itim Bilimleri Fakültesi Özel Eğitim Dergisi, $18(2), 253-269$.

Mercer, C. D., \& Miller, S. P. (1992). Teaching students with learning problems in math to acquire, understand, and apply basic math facts. Remedial and Special Education, 13(3), 19-35.

NCTM. (National Council of Teachers of Mathematics). (2000). Principles and standards for school mathematics. US: Reston. VA. 
Zihinsel Yetersizliği Olan Öğrencilere Matematiksel Kavram ve Becerilerinin Öğretimine Yönelik Öğretmenlerin Sınıf İçi Uygulamalarının Belirlenmesi

Rivera, D. P. (1997). Mathematics education and students with learning disabilities: Introduction to the special series. Journal of Learning Disabilities, 30(1), 2-19.

Sazak Pınar, E., ve Kocabıyık, D. (2014). Orta düzeyde zihinsel yetersizliği olan öğrencilere örüntü oluşturma becerisinin öğretiminde doğrudan öğretim yönteminin etkililiği, AIBBÜ Sosyal Bilimler Enstitüsü Dergisi, 14(3), 281-300.

Sönmez, S. (2014). Öğretmenlerin zihin engelli öğrencilerin matematik beceri kavram ve işlemlerini değerlendirme sürecinde yaptıklarının belirlenmesi. Yayınlanmamış yüksek lisans tezi. Abant İzzet Baysal Üniversitesi, Eğitim Bilimleri Enstitüsü, Bolu.

Soluaga, D., Leaf J.B, Taubman M., McEachin J., \& Leaf, R. (2008). A comparison of flexible prompt fading and constant time delay for five children with autism. Research in Autism Spectrum Disorders, 2(4), 753-765.

Stein, M. K. \& Bovalino, J. W. (2001). Manipulatives: One piece of the puzzle. Mathematics Teaching in the Middle School, 6(9), 356-359.

Şafak, P. (2007). Az gören öğrencilere eldeli toplama öğretiminde uyarlanmış basamaklı öğretim yönteminin etkisi. Türk Ĕgitim Bilimleri Dergisi, 5(1), 27-46.

Tuncer, T. (1994). Görme engelli öğrencilere basamak değeri ve eldeli toplama ögretiminde basamaklı ögretim yöntemiyle sunulan bireyselleştirilmiş ögretim materyalinin etkililiği. Yayımlanmamış doktora tezi. Gazi Üniversitesi/Sosyal Bilimler Enstitüsü, Ankara.

Tufan, S., ve Aykut, Ç. (2018). Şemaya dayalı strateji ve kendini izleme stratejisi öğretiminin hafif düzeyde zihinsel engelli öğrencilerin sözel matematik problemi çözme performanslarına etkisi, İlkögretim online, 17(2), 613-641

Tracy, D. M., \& Fanelli, B. H. (2000). Teaching money concepts: Are we shortchanging our kids? Educational Resources Information Center (ERIC). ED 451065.

Vural, M., ve Yıkmış, A. (2008). Kaynaştırma sınıfı öğretmenlerinin öğretimin uyarlanmasına ilişkin yaptıkları çalışmaların belirlenmesi. Abant İzzet Baysal Üniversitesi Eğitim Fakültesi Dergisi, 8(2), 141-159.

Yücesoy, Ş. (2002). Zihin özürlü öğrencilere fotokopi çekme becerisinin öğretiminde eşzamanlı ipucuyla ögretimin etkililiği. Yayınlanmamış yüksek lisans tezi. Anadolu Üniversitesi, Eğitim Bilimleri Enstitüsü, Eskişehir.

Yıkmış, A., ve Eldeniz Çetin, M.. (2010). Zihinsel yetersizliği olan öğrencilere sabit bekleme süreli öğretimle bölme öğretimi. Abant İzzet Baysal Üniversitesi Dergisi, 10(2), 69-78.

Yıımış, A. (2005). Etkileşime dayalı matematik öğretimi. Ankara: Kök Yayıncılık.

Yıldırım, A. ve Şimşek, H. (2008). Nitel araştırma yöntemleri. Ankara: Seçkin Yayıncılık

Yıldırım, A., ve Şimşek, H. (2005). Nitel araştırma yöntemleri. Ankara: Seçkin Yayıncılık. 